\title{
Warriewood
}

\section{Virginia Macleod}

Warriewood is on Sydney's northern beaches, between Mona Vale and North Narrabeen, in the Pittwater local government area.

This was once a 'wet' part of the coast. Lagoons and swamps were typical of the northern beaches and east coast of New South Wales. Narrabeen Creek flows through the middle of Warriewood, and Mullet Creek marks its southern boundary. Early nineteenth-century maps mark most of the land between the south-east corner of Pittwater across to Mona Vale Beach and south, including Warriewood Valley, as swamp. The local Guringai Aboriginal people would have found these swamps rich in food supplies - fish, birds, plants and naturally fresh water.

\section{Land grants and agriculture}

The first land grant in Warriewood was given to James Jenkins. In 1824 he received 1,000 acres (405 hectares) and the following year a further 250 acres (101 hectares), all of which he called Cabbage Tree Hill Farm. Cabbage tree palms were common along the peninsula. The palm fronds were used for thatch and hats, the trunks for fencing and building, and the pith was fed to livestock. By 1829 Jenkins had a weatherboard cottage, 14 horses and 440 horned cattle, and he had cleared 17 acres ( 7 hectares) and put up 300 rods (150 metres) of fencing. Local timbers ironbark, stringybark, grey gum, turpentine, mahogany and forest oak - were used for building, fencing, firewood and other purposes.

Later in the nineteenth century, the Macpherson family farmed Jenkins's land, which became known as Warriewood. Goods were taken to Sydney via Lane Cove Road, or overland to Manly and then by ferry to Sydney.

\section{Market gardens}

In 1906 the land was subdivided and advertised as suitable for both residential and farm blocks. A brochure by Henry Halloran promoting the sale referred to the 'salubrious' climate, the 'sheltered vale' protected from adverse winds, and the quality of the soil. It cited a

Mr Duffy, [who] with no labor but his own, obtained 43 pounds of peas from an acre and a quarter which less than a year before was bush-land.

Despite Halloran's sales pitch, market gardening seems to have only begun in the 1920s. Perhaps this had something to do with transport. In 1925 Roseville Bridge opened, and then in 1932 the Harbour Bridge, making it much easier to get goods to market in Sydney.

Market gardening is typically practised on the edges of cities, where land, water supply and labour are cheaper. Warriewood became known as 'Glass City', because at one time there were 3,500 glasshouses there. Production was at its peak in the period between 1947 and 1954, and 100 pounds (45 kilograms) of tomatoes per glass house each year was a profitable return. Field crops such as beans, potatoes, lettuce, carrots, peas, cabbage, marrow, beetroot and capsicum were also grown, but not under glass. 
Typically, market gardeners are recent migrants. This was certainly the case for Warriewood, which became home to Italians and people from the country then called Yugoslavia. Some Yugoslav families would offer work to newly arrived fellow-countrymen, and it is no surprise that the first Yugoslav club in Australia was started at Warriewood in 1939, at the corner of Vineyard Street and Warriewood Road. Several migrant families came from Broken Hill after the depression in the mining industry in 1932.

George Dunn moved there as a child in the 1920s and he remembers helping on the family farm with his eight siblings. As an adult, Dunn worked as a carrier. He collected tomatoes in crates from local farms in the evening and took them to market, leaving at 3 am, every day of the week.

From 1951, the state government restricted development in this area, as it was unable to provide the necessary infrastructure - water and sewerage. No building was allowed on any block smaller than two hectares (five acres) and rural zoning was established and maintained for this area.

\section{Farm to suburb}

By the 1960s, market gardening in the area had declined because produce shipped from other states was cheaper. As a result, some farmers redeveloped their land into nursery gardens. At the same time there was pressure from the community to allow subdivision. Some areas along Pittwater and Mona Vale Roads were rezoned to allow for commercial development. However, residential subdivision was only achieved in 1991 under the state government urban development plans. Gradually the rural character of Warriewood began to change, as the valley became a suburb. There was considerable planning for infrastructure (water, roads and other services) to accommodate more than 1,500 residential blocks and the approximately 5,000 or so people who would soon live there. Today street names in the new subdivisions - Apollo, Daydream, Jubilee and Ponderosa - are tributes to the varieties of tomatoes which once grew on the same land.

Virginia Macleod was local studies librarian at Mona Vale Library, Sydney, and works as a professional historian

\section{References}

Margrit Koettig, 'Ingleside Warriewood Urban Land Release Assessment of Aboriginal Sites', 1993

Joan Lawrence, Pittwater Paradise, Kingsclear Books, Crows Nest, NSW, 1994

Joan Lawrence, Pittwater Pictorial History, Kingsclear Books, Alexandria, NSW, 2006

John Morcombe, 'Rural nature disappearing', Manly Daily, 4 April 2000

Mary Stenning, 'Yugoslav Tomato Glass House Growers, Warriewood', Manly Warringah Journal of Local History, vol 6, March, 1995

Tropman and Tropman Architects, 'Ingleside Warriewood Urban Land Release Heritage Study', 1993 